Отримано: $17.10 .2020 \mathrm{p}$.

Прорецензовано: 20.10.2020 p.

Прийнято до друку: 21.10.2020 p.

e-mail: bohdan.novak@oa.edu.ua

DOI: $10.25264 / 2409-6806-2020-30-78-83$
Новак Б. Василь Іванис та його погляди на минуле і майбутнє Кавказу. Наукові записки Національного університету «Острозька академія». Серія «Історичні науки». Острог, 2020. Вип. 30. С. 78-83.

\title{
Богдан Новак
}

\section{ВАСИЛЬ ІВАНИС ТА ЙОГО ПОГЛЯДИ НА МИНУЛЕ І МАЙБУТНС КАВКАЗУ}

У статті здійснено спробу аналізу поглядів украӥнського громадського діяча та публічиста на історію кавказького регіону. Охарактеризовано формування етноначіональної ідентичності В. Іваниса. Висвітлено його бачення проблем давньої історії Кавказу, російського підкорення регіону та політичної icmopiï XX cm.

Ключові слова: Кавказ, Василь Іванис, Кубань, Російська імперія.

\section{Bohdan Novak}

\section{VASYL IVANYS AND HIS VIEWS ON THE PAST AND FUTURE OF THE CAUCASUS}

Vasyl Ivanys (1888-1974) is an extraordinary personality of the Ukrainian political and cultural world of the XX century. He was a politician and public figure, engineer, economist, publicist and historian. Exept this, the person of Vasyl Ivanys is interesting because he, as a native of the North Caucasus, directly knew this part of the world, its history, the course of the revolutionary events of 1917-1921, and, unlike other famous figures of Kuban or Ukraine at that time, left a complex idea of the region in the published work «On the problem of the Caucasus». The ideas and views expressed in this publication are the subject of this paper. In addition to "On the problem of the Caucasus», the source base includes the first two volumes of Vasyl Ivanys memoirs of "Paths of Life», publications «Another tragedy of the Cossacks» and «The Kuban struggle for independence».

The article pays a lot of attention to the identity of Vasyl Ivanys, which was due to its origin. First of all, he was a Cossack, a native of the North Caucasus, but at the same time he felt his belonging to the Ukrainian cultural space. His publication "On the Problem of the Caucasus» focuses mainly on the ancient history of the region, Russia's conquest of the Caucasus, the resettlement of the Cossacks in the Kuban, the revolution of 19171918 in the North Caucasus and the future of this part of the world.

The author of the article concludes that Ivanys views on the history and future of the Caucasus region, expressed in the "On the problem of the Caucasus», due to the origin and its political orientation. The Kuban occupies a central place in the publication, but Vasyl Ivanys covers its history in the general historical context and emphasizes its belonging to the North Caucasus. Although "On the Problem of the Caucasus» is based on extensive bibliographic material, but has a journalistic character. At the same time, Ivanys publication remains one of the few generalizations in Ukrainian historiography that covers the history of the Caucasus from ancient times to the second half of the XX century, gives an idea of the economic and cultural potential of the region and reflects the geopolitical ideas prevailing in Ukrainian politics emigration.

Key words: Caucasus, Vasyl Ivanys, Kuban, Russian Empire.

Василь Миколайович Іванис (1888-1974) - непересічна постать українського політичного та культурного світу XX ст. Він походив із родини кубанських козаків. Здобув чудову інженерну та економічну освіту в середньотехнічній школі м. Ростов, Московському комерційному інституті, Політехнічному інституті Новочеркаська. У 1910 р. відбував службу в 3-му Кубанському пластунському батальйоні в Грузії, а в 1915 р. вступив до Михайлівської гарматної школи, після закінчення якої був відправлений на Кавказький (Турецький) фронт, де брав участь у Трапезундській операції. Згодом, як інженера-технолога, його відправлено на військовий завод з вироблення синтетичного фенолу ${ }^{1}$ біля Олександрівська-Грушевського на Донбасі, де він і зустрів революційні події в Російській імперії

\footnotetext{
${ }^{1}$ Речовина, яку застосовували для виготовлення снарядів.
} 
[20, с. 81]. В подальшому В. Іванис став одним з найбільш активних та ключових діячів Кубані, як під час революційних подій, так і в еміграції. Щоб уникнути штивних фраз і зайвої для нашого дослідження періодизації подальшого життя героя нашої статті, використаємо слова бібліографа Лева Биковського, який особисто знав В. Іваниса і спробував ще за його життя дати характеристику його

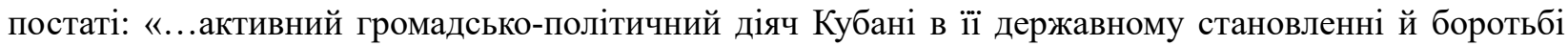
на два фронти (білому і червоному), член кубанського парламенту, iї міністр промисловості, голова кубанського уряду, і нарешті, останній отаман вільної Кубані, згодом на еміграції - професор УГА, УТГІ та українського Технічного ліцею в Черницях, член УВАН, НТШ й Українського Науковго інституту в Варшаві, педагог і науковець, автор багатьох підручників, науково-дослідчних розвідок, невтомний науково-культурний діяч еміграції» [2, с. 124]. Крім того, особа В. Іваниса цікава тим, що він, як уродженець Північного Кавказу, безпосередньо знав цю частину світу, їі історію, перебіг революційних подій 1917-1921, i, на відміну від інших відомих постатей Кубані чи України того часу, залишив комплексне уявлення про регіон в розвідці «До проблеми Кавказу» [12]. Висловлені в ній ідеї та погляди автора є предметом дослідження цієї статті.

Попри те, що В. Іванис є значною постаттю української історії XX ст., досі не маємо монографічного дослідження про нього. Крім енциклопедичних гасел [4; 17] та публіцистичних статей, діяльність та погляди українського діяча почасти знайшли відображення в публікаціях Вадима Задунайського [10], Володимира Сергійчука [21], Рената Польового [20] та Лева Биковського [2].

Крім вказаної праці «До проблеми Кавказу», до джерельної бази дослідження входять перші два томи спогадів В. Іваниса «Стежками життя» $[13 ; 14]$ і публікації «Ще одна трагедія козаків» [11] та «Боротьба Кубані за незалежність» [15].

Для кращого розуміння контексту та того, чим, в уявленні В. Іваниса, був Кавказ, варто зупинитися на питанні його етнонаціональної ідентичності. Кубань (Кубанський край, Кубанська область) займає центральне місце майже у всіх дотичних до історії працях автора. Це вісь, навколо якої обертаються головні сюжети описуваних ним подій. Ця територія охоплює сучасні Адигею, Карачаєво-Черкесію і Краснодарський край Російської Федерації [6, с. 8]. Кубанські козаки також заселяли територію так званої «Чорноморщини» (Чорноморська губернія) - це частина сучасного Краснодарського краю вздовж узбережжя Чорного моря, де проживали черкеси-шапсуги, яка була відділена від Кубанської області в 1996 р. Ці землі, заселені козаками, є частиною Кавказу, але водночас належать до українського етнічного та культурного простору. Власне розуміння зв'язку України та Кубані В. Іванис описав в своїх спогадах, написаних від третьої особи: «Увесь сенс свого буття на землі він (B. Іванис. - Б. Н.) бачив в поборюванні окупантів червоних чи білих на Кубані чи Україні. Кубань - його найближча Батьківщина, але він ніколи не прихилявся до протиставлення Кубані Україні, бо завжди був переконаним, що вони мусять існувати лише доповнюючи одна одну. Інші, інаковірні, українські землі набули певного значення лише пізніше, коли ближче їх пізнав» [13, с. 185].

Згідно з першим переписом населення в Російській імперії 1897 р. етнічний розподіл населення Кубанської області виглядав так: українці - 47,36\%, росіяни $-42,56 \%$, черкеси $-2,1 \%$, карачаївці - 1,4\%, решту становили німці, вірмени, греки, білоруси, поляки та ін. В Чорноморській губернії ситуація була дещо іншою: росіяни - $42,8 \%$, українці $16,9 \%$, вірмени - $10,9 \%$, греки $-10,4 \%$, черкеси $3,3 \%$, осетини $3,3 \%$ та ін. Специфіка життя в регіоні сприяла тому, що не тільки нащадки кубанських козаків переймали місцеві культурні особливості, що виявлялось в одязі чи зброї, але і представники гірських народів вливалися в українське політичне життя. Наприклад, один з майбутніх лідерів комуністичної Адигеї Шахан-Гирей Хакурате був членом Революційної Української Партії [9,с 119], що розповсюдила свою діяльність на Кубані на початку XX століття (в тому числі зусиллями Симона Петлюри). Окремі представники народів Кавказу під час революційних подій виступали за союз Кубані з Україною, зокрема міністр юстиції кубанського уряду черкес Айтек Наміток [14, с. 122].

Цікаве спостереження про етнонаціональну ідентичність та риси характеру В. Іваниса можна зробити, порівнюючи його спогади з мемуарами Л. Биковського. Останній також воював на Кавказькому фронті Першої Світової і залишив цікаві спомини як про хід війни, так і про регіон, під назвою «На Кавказько-Турецькому фронті» [3]. Будучи українцем з Наддніпрянщини, він захоплювався красою гір Кавказу, колоритним життям місцевої людності. Його він цікаво описав у своїй подорожі через Новоросійськ, Баку, Тбілісі, Батумі, обрамлюючи свої враження в майже поетичні конструкції на кшталт «потужні таємничі гори», «сильветки їздців у чорних кавказьких, повстяних бурках», «невеличка, але привітна залізнична станція Батум» або «гордий виклик Кавказу, в який я, мешканець 
розлогих степів України, в’їздив з цікавістю і деяким острахом, і який мене на все життя полонив» [3, с. 13-23]. В. Іванис також писав про красу кавказьких гір, їхню природу, людей, але як про свій і зрозумілий край, де майже в будь-якому місці можна зустріти знайомих. А художні обертони характерні більше для першого тому його спогадів, в якому він описує свої дитячі та юнацькі роки. Загалом стиль його письма вирізняється лаконічністю та виразністю думок, простежується намагання бути максимально об’єктивним у своїх судженнях, відокремлювати головне від другорядного, уникати зайвих деталей. Можливо саме тому слова В. Іваниса в передмові до спогадів Л. Биковського «На кавказько-турецькому фронті» звучать досить некомпліментарно: «На мою думку праця інж. Л. Биковського обтяжена поясненнями і літературними додатками. Опріч того в ній забагато подробиць і мало помічні мапки» [3, с. 8]. В його публікаціях основну увагу зосереджено на військовополітичних подіях, натомість «цивільно-національне життя різних країн, людей і солдатів» [3, с. 8] цікавило його значно менше.

Розвідка «До проблеми Кавказу» було опубліковано 1960 р. видавництвом «Українські вісті». Вона складається 333 коротких розділів, які в стислій формі висвітлюють історію Кавказу від найдавніших часів до становища, в якому він опинився після Другої Світової війни. Під час роботи над дослідженням В. Іванис використовував доступні йому описово-статистичні джерела [5], а також праці українських та кубанських дослідників, зокрема Михайла Грушевського [7; 8], Олександра Лотоцького [19], Івана Івасюка [16], Павла Сулятицького [22], Федора Щербини [25]. На нашу думку, використання публікацій останнього було не тільки цілком виправданим, але й стало своєрідним омажем великому кубанцю, статисту та історику. Крім цього, В. Іванис послуговується працями кавказьких діячів, що з'явились в еміграції. Наприклад, публікаціями часопису «Caucasian Rewiev», який видавав Інститут з вивчення історії та культури СРСР у Мюнхені. Висвітлюючи сталінські депортації гірських народів наприкінці Другої Світової війни, автор використовує і до сьогодні широко цитовану статтю Григорія Токаєва «Упокорення Північного Кавказу» [23]. В розвідці бачимо також часті покликання на спогади представників білого руху, зокрема Антона Денікіна, Петра Краснова, Олександра Лукомського та ін.

Перші розділи публікації присвячені загальному історичному, статистичному та географічному опису території. В. Іванис підкреслив економічне значення Кавказу, який, за його словами, за територією більший багатьох європейських країн, переважає їх за кількістю населення та багатством природних ресурсів, але, попри це, залишається периферією світу [12, с. 9]. Щоб пояснити такий стан речей, автор «бодай найкоротше» зупинився на «попередніх історичних епохах», подаючи фрагментарні й стислі відомості про найдавніші державні регіону, як наприклад: «Азербайджанський ханат до XVIII ст. був під протекторатом перських шахів. Та по закінченні російсько-турецької війни за угодою з рр. 1877-1878 Азербайджан зі своїм «чорним золотом» і м. Баку був анексований Росією. Головну масу населення (60\%) становлять татари і вірмени (12\%). Решта населення Азербайджану це різні гірські племена, грузини, перси, росіяни, українці та ін.» [12, с. 6]. Так само лапідарно зазначено й про Вірменію: «Вірменія заселена народом 3 дуже давньою культурою . Християнство вони прийняли ще в III ст. Протягом III-х століть вірмени вже мали прастару автократичну, релігійного типу державу. Вірмено-григоріянське визнання цілком незалежне і очолюється власним єпископом Католікосом, який здавніх часів має сталий осідок в м. Ечміядзіні. Пізніше Туреччина анектувала Вірменію. В ХІХ ст. велика частина Вірменії була приєднана до Росії і з неї утворено Еріванську губернію» [12, с. 7]. Найбільше уваги приділено Грузії, зважаючи на історію їі державності, якій вдалося перетворитися, бодай на короткий період, на сильного, самостійного гравця за часів правління Давида Відновителя (Будівничого) та цариці Тамари в XI-XIII ст. [12, с. 10]. Детальніше В. Іванис зупиняється на історії підкорення терену Римом, Персією, Візантією, Арабським халіфатом, монголами і згодом імперією Романових. На висвітленні В. Іванисом історії підкорення Кавказу Росією варто зупинитись окремо.

Як можна зрозуміти, головну причину російського завоювання В. Іванис вбачає в економічній привабливості регіону. Проте після затяжної кавказької війни та остаточного приєднання цей край більше не привертав уваги метрополії і перетворився на звичайний сировинний додаток: «Ніяких вкладів капіталу російський уряд робити не квапився. Особливих досліджень, крім приватних, частіше чужинецьких, підприємств на цій території не провадилося. Експлуатувалось те, що само йшло до рук, як от нафта в Баку, Грозному, Майкопі, марганцева руда в Чіятурах, мідь добувалась у Вірменії. Високої якості цемент з натурального мергелю в Новоросійському. В нафтову промисло- 
вість Кавказу вкладено самого англійського капіталу 171,4 млн. рублів, а загалом вкладу 307,7 млн., або $51,8 \%$, а решту капіталів становили шведські, американські, татарські вклади. Наймізернішу долю вкладів становили російські» [12, с. 17]. Звісно, наведені вище відомості важко заперечити. В. Іванисом Кавказ сприймався як аналог колоніальних володінь європейських держав, як символ російської могутності, і був такою ж перлиною в царській короні - як Індія в Британській Однак, економічну відсталість регіону, що так болить В. Іванису, він пояснював не лише його колоніальним становищем, а й способом його підкорення. На його думку, приєднання Кавказу до Росії було тісно пов'язане з російсько-турецьким та російсько-персидським суперництвом в регіоні, де економічні інтереси відігравали незначну роль. Поширені в XVIII ст. уявлення про багатства південних земель та величезні поклади кольорових металів виявились неправильними. Не були виправдані і розрахунки на Балтійсько-Каспійський транзит [18, с. 30-31]. Власне російських фінансових вливань не було достатньо для розвитку регіону, тому залучались іноземні інвестиції, як і в інших окраїнах імперії. На Кавказі ж імперія обмежувалася своєю «культурницькою» цивілізаційною місією: відкриттям шкіл, бібліотек, театрів, наукових товариств, парків, брукованих вулиць і т. п. [1, с. 118]

Одним із лейтмотивів розвідки «До проблеми Кавказу» є обгрунтування прав українців (слов'ян, козаків) на заселені ними землі. Тут В. Іванис апелює до історії напівлегендарного «українського» Тмутороканського князівства, яке нібито проіснувало на Таманському півострові 350 років [12, c. 10] і уславилося героїчною боротьбою проти косогів (черкесів), греків, італійців, та впало тільки під тиском монголів [12, с. 10]. Поновна поява українців і колонізація кубанських степів нащадками запорозьких козаків наприкінці XVIII ст. подається (до певної міри справедливо) як вимушена, продиктована політикою Російської імперії: «Українські козаки прибули сюди не як завойовники, якими були татари з Золотої орди в Криму чи на Кубані. Вони самі були ізгої, пограбовані росіянами на Запоріжжі і позоставили цілі маєтки, аби лише зберегти себе від закріпачення, що його окупаційна російська влада завела по цілій Україні» [12, с. 15]. Тим самим автор прирівнював козаків до поневолених гірських народів Кавказу, показував, що вони були інструментом в руках російської політики. Ба більше, за В. Іванисом, кубанці відчували значно більший русифікаційний тиск, ніж інші народи Кавказу, адже «в Грузії і Вірменії священниками були грузини і вірмени, карачаївці, черкеси мали мул із свого населення, а на Кубані душпастирі були переважно русифікатори» [12, с. 17]. Автор абстрагується від ідеї, що українці були також бенефіціарами колоніальної політики на Кавказі, а козаки привілейованої верствою і скоріше займали колоніальну сторону, аніж були упослідженими як гірське населення Північного Кавказу. І хоча В. Іванис не оминає фактів про методи, якими проводилося завоювання Північного Кавказу і згадок про виселення автохтонного населення зі своїх земель (мухаджирство), але в тексті відсутня згадка про переселення ногайців в кінці XVIII ст., чиї землі в підсумку зайняли кубанські козаки. Очевидно, український громадський діяч зараховує їх до нащадків завойовників-монголів, а тому, ймовірно, їхнє переселення у заволзькі степи не було аж такою великою несправедливістю.

Центральне місце в аналізованій праці займає опис революції на Кубані. В. Іванис детально змалював перебіг подій, учасником яких він був: створення Кубанської влади, заснування Добровольчої Армії, конфлікти всередині білого руху на терені Північного Кавказу, хід бойових дій і постання нових державних утворень: Грузії, Вірменії, Азербайджану, Республіки Горців Кавказу та ін. Не оминається й проблема етнічних взаємин козаків та гірських народів. Відзначено позитивну роль черкесів та карачаївців, що населяли Кубанський Край, які зайняли ворожу до більшовиків позицію і вели 3 ними постійну збройну боротьбу, створивши спочатку черкеський кінний полк, а потім черкеську кінну дивізію [12, с. 24]. Представники черкеського народу Касполет Улагай, Кучук Натірбе, Шахим Султан Гірей, Айтек Наміток, Мурат Хатагогу, Сефербі Сіюхо увійшли до Кубанської законодавчої ради та Кубанського уряду [24, с. 64]. Однак їх участь в політичному житті Кубані була значною мірою продиктована обставинами, адже адизькі народи були розділені і не створили окремих органів державної влади [24, с. 24].

Після «ілюстрацій життя на Кавказі після революції 1917 р. до його нової окупації Совєтською Росією» [12, с. 59] автор вдається до аналізу причин поновного поневолення краю. Звісно, до них він відносить конфлікти та слабку координацію дій між новопосталими державними організмами в регіоні: «Республіка Горців Північного Кавказу, Чорноморщини і Ставропільщини проти більшовиків виступали окремими партизанськими групами, не створивши суцільного фронту. Закавказькі республіки (Азербайджан, Вірменія й Грузія) кожна окремо пробували боронитися аж тоді, коли 
совєтські дивізії переходили (без попередження) їхні кордони. Боротьба [...] всіх їх була короткою і незмінно програною» [12, с. 59]. В. Іванис схильний ідеалізувати заслуги кубанців, які боролися як проти червоних, так і проти білих, тоді як інші вбачали загрозу тільки від «червоних імперіалістів» $[12$, c. 59-60].

В розділі про Другу Світову війну на Кавказі, автор вдається до розлогого цитування статті Г. Токаєва, переповідаючи перебіг депортацій чеченців, інгушів, карачаївців та балкарців [12, с. 6667]. Загалом він малоінформативний і служить ще однією ілюстрацією героїчної i, водночас, трагічної сторінки в історії Кавказу.

Завершальна частина розвідки нагадує політичну програму, в якій автор коротко окреслив своє бачення перспектив кавказького регіону. За В. Іванисом, весь Кавказ повинен об'єднатися у федеративний союз, до якого ввійшли б Грузія, Вірменія, Азербайджан, Дагестан, Терек, Ставропільщина, Кубань і Чорноморщина [12, с. 69-70]. Тобто, до нового державного організму повинні ввійти не тільки території Північного і Південного Кавказу з автохтонним населенням, але і землі, населені некавказькими народами. Після об'єднання нова федерація зможе увійти до ширшого союзу країн, що знаходяться в басейні Чорного моря. Як бачимо, ці погляди перегукуються з Чорноморською доктриною Юрія Липи. Проте, на відміну від останнього, В. Іванис відносить етнічно українську Кубань до федеративного Кавказу. Це можна пояснити походженням, ідентичністю автора та кращим розумінням специфіки життя в регіоні.

Погляди В. Іваниса на історію та майбутнє кавказького регіону, висловлені в розвідці «До проблеми Кавказу», зумовлені походженням автора. Центральне місце в публікації займає Кубань, однак В. Іванис висвітлює її історію в загальному історичному контексті і підкреслює її належність до Північного Кавказу. Хоча розвідка й грунтується на широкому бібліографічному матеріалі, але має публіцистичний характер. Разом з тим, праця «До проблеми Кавказу» залишається одним з небагатьох узагальнень в українській історіографії, які висвітлюють історію Кавказу від найдавніших часів до другої половини XX ст., дає уявлення про економічний та культурний потенціал регіону і відбиває уявлення про геополітичні ідеї, які панували в середовищі української політичної еміграції.

\section{Список використаних джерел та літератури:}

1. Rohoziński J. Najpiękniejszy klejnot w Carskiej koronie. Gruzja pod panowaniem rosyjskim 1801-1917. Warszawa, 2018. $291 \mathrm{~s}$.

2. Биковський Л. Василь Іванис Стежками життя. Спогади. Украӥнський історик. 1967. Ч. III-IV (15-16). C. $124-128$.

3. Рец. на кн.: Іванис В. Стежками життя. Спогади. Т. 1-5. Буенос-Айрес, Новий Ульм, 1958-1962. Т. 1.191 с; т. 2.366 с; т. 3.348 с; т. 4.402 с; т. 5.515 с.

4. Биковський Л. На кавказько-турецькому фронті. Вінніпег, 1968. 154 с.

5. Богуславський О. Іванис Василь. Українське козаџтво: мала енциклопедія. Київ ; Запоріжжя, 2002. C. 178 .

6. Бутков П. Материалы для новой истории Кавказа. Т.3. Санкт Петербург, 1869. 621 с.

7. Вачагаев М. Союз горцев Северного Кавказа и Горская республика. История несостоявшегося государства. Москва, 2018. 500 с.

8. Грушевський М. С. Історія України-Руси. Т. 1. Київ, 1913. 648 с.

9. Грушевський М. С. Історія України-Руси. Т. 2. Львів, 1905. 708 с.

10. Дэрлугьян Г. Горские князья, партвыдвиженци и помидорщики: двести лет социальной эволюции адигейских элит. Политическая конщептология. 2018. № 4. С. 99-132.

11. Задунайський В. Особливості діяльності лідерів Кубані під час революційних зрушень 19171920 - х pp. (на прикладі Василя Іваниса та Андрія Шкуро). URL: http://www.irbis-nbuv.gov.ua/cgi-bin/irbis nbuv/cgiirbis_64.exe?I21DBN=LINK\&P21DBN=UJRN\&Z21ID=\&S21REF=10\&S21CNR=20\&S21STN=1\&S21 $\overline{\mathrm{F}}$ $\mathrm{MT}=\mathrm{ASP}$ meta\&C21COM=S\&2_S21P03=FILA=\&2_S21STR=ipc 2016_1_6. (дата звернення: 25.09.2020).

12. Іванис В. Боротьба Кубані за незалежність. Мюнхен, $196 \overline{8} .137 \overline{\mathrm{c}}$.

13. Іванис В. До проблеми Кавказу. [Б. м.], 1960. 70 с.

14. Іванис В. Стежками життя. Спогади. Т. 1. Торонто, 1958. 191 с.

15. Іванис В. Стежками життя. Т. 2. Новий Ульм, 1959. 366 с.

16. Іванис В. Ще одна трагедія козаків. [Б. м.], 1961. 36 с.

17. Івасюк I. Кубань. Економічний нарис. Прага, 1925. 204 с.

18. Ковальчук О. Іванис Василь Миколайович. Енциклопедія історії Украӥни. Т. 3. Київ, 2005. С. 397.

19. Лапин В. История Кавказской войны. Пособие к лекционному курсу. Санкт Петербург, 2003. 82 с.

20. Лотоцький О. Сторінки минулого. Т. 2. Варшава, 1933. 486 с.

21. Польовий Р. Кубанська Україна. Київ, 2002. 303 с.

22. Сергійчук В. Північний Кавказ: українські аспекти заселення, розвитку господартва та національної свідомості. Київ, 2014. 294 с.

23. Сулятицький П. Нариси з історії революції на Кубані. Т. 1. Прага, 1926. 197 с. 
24. Токаев Г. Усмирение Северного Кавказа. Социиалистический вестник, 1951. С. 65-67.

25. Трахо Р. Черкесы. Мюнхен, 1956. 145 с.

26. Щербина Ф. А. История Кубанского казачьего войска. Т. 2. Екатеринодар, 1913. 848 с.

\section{References}

1. Rohozinski J. Najpiekniejszy klejnot w Carskiej koronie. Gruzja pod panowaniem rosyjskim 1801-1917. Warszawa, 2018. $291 \mathrm{~s}$. 128 .

2. Bykovskyi L. Vasyl Ivanys Stezhkamy zhyttia. Spohady. Ukrainskyi istoryk. 1967. Ch. III-IV (15-16). S. 124-

3. Rets. na kn.:Ivanys V. Stezhkamy zhyttia. Spohady. T. 1-5. Buenos-Aires, Novyi Ulm, 1958-1962. T. 1. 191 s; t. $2.366 \mathrm{~s}$; t. $3.348 \mathrm{~s}$; t. $4.402 \mathrm{~s}$; t. $5.515 \mathrm{~s}$.

4. Bykovskyi L. Na kavkazko-turetskomu fronti. Vinnipeh, 1968. $154 \mathrm{s.}$

5. Bohuslavskyi O. Ivanys Vasyl. Ukrainske kozatstvo: mala entsyklopediia. Kyiv ; Zaporizhzhia, 2002. S. 178.

6. Butkov P. Materialy dlya novoy istorii Kavkaza. T.3. Sankt Peterburg, 1869. $621 \mathrm{~s}$.

7. Vachagaev M. Soyuz gortsev Severnogo Kavkaza i Gorskaya respublika. Istoriya nesostoyavshegosya gosudarstva. Moskva, 2018. 500 s.

8. Hrushevskyi M. S. Istoriia Ukrainy-Rusy. T 1. Kyiv, 1913. 648 s.

9. Hrushevskyi M. S. Istoriia Ukrainy-Rusy. T 2. Lviv, 1905. 708 s.

10. Derlug'yan G. Gorskie knyaz'ya, partvydvizhentsi i pomidorshchiki: dvesti let sotsial'noy evolyutsii adigeyskikh elit. Politicheskaya kontseptologiya. 2018. № 4. S. 99-132.

11. Zadunaiskyi V. Osoblyvosti diialnosti lideriv Kubani pid chas revoliutsiinykh zrushen 1917-1920 - kh rr. (na prykladi Vasylia Ivanysa ta Andriia Shkuro). URL: http://www.irbis-nbuv.gov.ua/cgi-bin/irbis nbuv/cgiirbis 64. exe?I21DBN=LINK\&P21DBN=UJRN\&Z21ID $=\& S 21 \mathrm{REF}=10 \& \mathrm{~S} 21 \mathrm{CNR}=20 \& \mathrm{~S} 21 \mathrm{STN}=1 \overline{\mathrm{S}} 21 \mathrm{FMT}=\mathrm{ASP}$ meta\&C21COM=S\&2_S21P03=FILA=\&2_S21STR=ipc_2016_1_6. (data zvernennia: 25.09.2020).

12. Ivanys V. Borotba Kubani za nezaležhnist. Miunkhen, $1 \overline{96} \overline{8} .137 \mathrm{~s}$.

13. Ivanys V. Do problemy Kavkazu. [B. m.], 1960. $70 \mathrm{~s}$.

14. Ivanys V. Stezhkamy zhyttia. Spohady. T. 1. Toronto, 1958. $191 \mathrm{s.}$

15. Ivanys V. Stezhkamy zhyttia. T. 2. Novyi Ulm, 1959. S. 366 s.

16. Ivanys V. Shche odna trahediia kozakiv. [B. m.], 1961. $36 \mathrm{~s}$.

17. Ivasiuk I. Kuban. Ekonomichnyi narys. Praha, 1925. 204 s.

18. Kovalchuk O. Ivanys Vasyl Mykolaiovych. Entsyklopediia istorii Ukrainy. T. 3. Kyiv, 2005. S. 397.

19. Lapin V. Istoriya Kavkazskoy voyny. Posobie k lektsionnomu kursu. Sankt Peterburg, 2003. 82 s.

20. Lototskyi O. Storinky mynuloho. T. 2. Varshava, 1933. 486 s.

21. Polovyi R. Kubanska Ukraina. Kyiv, 2002. 303 s.

22. Serhiichuk V. Pivnichnyi Kavkaz: ukrainski aspekty zaselennia, rozvytku hospodartva ta natsionalnoi svidomosti. Kyiv, 2014. 294 s.

23. Suliatytskyi P. Narysy z istorii revoliutsii na Kubani. T. 1. Praha, 1926. $197 \mathrm{s.}$

24. Tokaev G. Usmirenie Severnogo Kavkaza. Sotsialisticheskiy vestnik, 1951. S. 65-67.

25. Trakho R. Cherkesy. Myunkhen, 1956. $145 \mathrm{~s}$.

26. Shcherbina F. A. Istoriya Kubanskogo kazach'ego voyska. T. 2. Ekaterinodar, 1913. 848 s. 